\title{
Dietary or in ovo Saccharomyces cerevisiae Supplementation Developed Growth, Caecal Microbiota and Gut Histology of Broiler Chicks
}

\author{
Salih Gulen, Isa Coskun*
}

Department of Animal Science, Agricultural Faculty, Ahi Evran University, 40000 Kurşsehir, Turkey

\section{A R T I C L E I N F O}

Research Articles

Received 30 January 2018

Accepted 23 February 2018

Keywords:

In ovo injection

Saccharomyces cerevisiae

Broiler

Performance

Villi growth

"Corresponding Author:

E-mail: isa.coskun@ahievran.edu.tr

\section{A B S T R A C T}

The aim of this study was to determine the effects of in ovo injection of Saccharomyces cerevisiae $(S C)$ to fertile Ross 308 broiler eggs or dietary supplementation on growth performance, internal organ development, gut histomorphology and cecum microbiota during $14 \mathrm{~d}$ of growing period. This study was designed as $2 \times 2$ factorial experimental design. Fertile 92 Ross 308 eggs were injected with SC solution $0.2 \mathrm{ml}$ at $18 \mathrm{~d}$ of hatch and 90 eggs noninjected as control, afterward dietary SC supplementation was applied during the $14 \mathrm{~d}$ to broiler diet. In this study, 160 broiler chicks were used in four treatment groups at 10 replicate for each treatment group and 4 chicks for each replicates. Treatment groups were A) in ovo $S C$ injection + dietary $S C$ supplementation, B) in ovo $S C$ injection + basal diet, C) no injection + dietary $S C$ supplementation, D) no injection + basal diet as control. Live weight, feed consumption, feed conversion ratio and gut histomorphology, caecum microbiota, internal organ weight were recorded at 14 days of age. Live weight gain increased in $\mathrm{C}$ group than in the D group. Feed consumption, feed conversion ratio and internal organ weights were not affected by the treatments. Villi length and villi width increased in A group among the other treatment groups in jejunum, villi length increased in A and $\mathrm{C}$ groups among the other groups in ileum. Villi length/villi width ratio increased in A group than in the D group in ileum, was not different in jejunum. LAB counts in caecum were higher in A group than those of C and D groups, but was not different from B group. Enterobactericaea count was lower in A and B group than in the D group, was not different from $\mathrm{C}$ group. To conclude, results showed that dietary Saccharomyces cerevisiae supplementation increased broiler growth at 14 day by increasing villi development and improving gut health.

\section{Saccharomyces cerevisiae İn ovo ve/veya Yeme İlave Yoluyla Etlik Piliçlerin Bağırsak Histolojileri, Sekal Mikrobiyotaları ve Büyümelerini İyileștirdi}

\begin{tabular}{lc} 
M A K A L E B İ L G İ S İ & Ö \\
\hline AraştırmaMakalesi & B \\
Geliş 30 Ocak 2018 & 1 \\
Kabul 23 Şubat 2018 & k \\
\hline
\end{tabular}

Anahtar Kelimeler:

İn ovo enjeksiyon

Saccharomyces cerevisiae

Broiler

Performans

Villi büyümesi

"Sorumlu Yazar:

E-mail: isa.coskun@ahievran.edu.tr
Ö Z E T

$\mathrm{Bu}$ çalışmanın amacı döllü etlik piliçlerde döllü kuluçkalık yumurtalara Saccharomyces cerevisiae enjeksiyonunun veya civcivlerin rasyonuna Saccharomyces cerevisiae ilavesinin ilk 14 günlük dönemde büyüme performansı, bağırsak histolojisi, sekum mikrobiyolojisi ve iç organ gelişimi üzerine etkilerini belirlemektir. Araştırmada $2 \times 2$ faktörüyel deneme deseni kullanılmıștır. 92 adet döllü etlik piliç yumurtalarına Saccharomyces cerevisiae enjeksiyonu yapılmıştır, 90 adet ise kontrol grubu olarak bırakılmıştır. Kuluçkadan sonra çıkan civcivlerin yemlerine Saccharomyces cerevisiae ilavesi yapılan ve yapılmayan grup oluşturulmuştur. Kuluçkadan sonra 160 adet bir günlük yaşta broyler civcivleri 4 muamele grubuna ve her muamele grubunun 10 tekerrürürüne, her tekerrürde 4 hayvan (2 dişi, 2 erkek) olacak șekildedağıtılmıștır. Muamele grupları A) enjeksion + rasyona ilave, B) enjeksiyonsuz + rasyona ilave, C) enjeksiyon + rasyona ilavesiz, D) enjeksiyonsuz + rasyona ilavesiz (kontrol) şeklinde düzenlenmiştir. Canlı ağıllık, emtüketimi, yemden yararlanma oranı, bağırsak histolojik parametreleri ve iç organ ağırlıkları 14 günlük yaşta kaydedilmiștir. Canlı ağırlık artışı C grubunda D grubuna gore yüksek bulunmuştur. Yem tüketimi, yemden yaralanma oranı ve iç organ ağırlıkları bakımından gruplar arasında farklılık gözlenmemiştir. Jejunumda villi yüksekliği ve villi kalınlığı A grubunda diğer muamele gruplarına göre yüksek bulunmuştur. Ileumda ise A grubunda villi yüksekliği diğer gruplara göre artmıştır. Ileumda villi yüksekliği/villi kalınlığ 1 oranı $A$ grubunda $D$ grubuna göre artmıștır, jejunumda ise değişmemiş̧tir. Laktik asit bakteri (LAB) sayısı A grubunda C ve D grubuna göre yüksek bulunmuştur. Enterobactericaea sayısı A ve B gruplarında D grubuna göre daha düşük bulunmuştur. $\mathrm{Bu}$ çalışmanın sonuçları rasyona simbiyotik ilavesinin etlik piliçlerin büyümelerini bağırsaklarda villi gelişimi ve bağırsak mikrobiyolojisini iyileştirerek arttırdığı belirlenmiştir. 


\section{Introduction}

The gastro-intestinal tract is the first place where digestive and absorption of nutrients and the first organ coming into contact with bacteria. Thus gut health is one of the most important factors for profitability in poultry production. Doe to banning of antibiotics as growing parameters, probiotics have gained importance as an alternative feed additive to improve gut health for a better development and growth. Saccharomyces cerevisiae is one of the most important of probiotics that is used for beneficial effects. But, the results of earlier studies of dietary $S C$ supplementation on weight gain are contradictory. For instance, it was reported that dietary $S C$ supplementation increased broiler weight gain (Mendieta et al., 2017; Çelik et al., 2001); Santin et al., 2001; Jayanese et al., 2017; Koç et al., 2010; Chen et al., 2017a). However, there are also some findings concluded that dietary SC supplementation did not affect broiler weight gain (De Souza et al., 2018, Gunal et al., 2006; Karaoglu and Durdag, 2005; Teng el al., 2017). The contradictory results on growth performance in broiler may be attributed to the fact that probiotics cannot show activity in the intestinal system of broilers. Because, Chen et al., (2017b) reported that dietary SC supplementation did not affect body weight gain, caecal lactic acid bacteria (LAB), Enterococcus, total anaerobic bacteria and short chain fatty acids. Also it was reported that dietary $S C$ supplementation did not affect body weight gain and caecal LAB count of broilers although dietary SC supplementation increased villi length and total volatile fatty acids and decreased caecal E. Coli (Teng et al., 2017; Haldar et al., 2011). Ozturk and Yildirim, 2004 reported that performance of broiler depends on different factors such as environmental, genetic, sanitation, application method. In earlier studies, $S C$ supplemented into the diet. The efficiency of $S C$ in the intestine should be investigated in more detail. Because, the efficiency of $\mathrm{SC}$ in the intestine may differ according to different applications. For example, Coskun et al., 2017 reported that wood shaving floor increased efficiency of dietary $S C$ supplementation by increasing the quail performance and duodenum villi length. And also Yasar and Yegen, (2017) reported that $S C$ fermented food additive increased broiler growth. Saccoromices cerevisiae should be investigated more detailed studies or applications. There is no study on the investigating of in ovo SC injection with dietary supplementation effects in broiler chickens. In ovo injection of $S C$ to fertile broilers eggs afterwards dietary supplementation should be investigated with regarding the different parameters for intestinal development in broilers. Therefore the aim of this study was to determine the effects of in ovo $S C$ injection afterwards dietary $S C$ supplementation to diet on 14 days growth performance of broiler, internal organ development, duodenum, jejunum, ileum histomorhological parameters and caecal mifroflora of broilers chicks during 14 days of growing period.

\section{Materials and Methods}

This study was conducted at the Poultry Research Unit of Ahi Evran University, Kirsehir, Turkey. The practices and procedures for this experiment were reviewed and approved by the Ahi Evran University, Animal Ethics Committee (09-07/2014/3-1). Fertile 238 eggs (average $67.7 \pm 5 \mathrm{~g})$ were provided from a breeder flock at $40 \mathrm{wk}$ of age (Ross 308). These eggs were incubated under optimal conditions (Eggs were incubated at $37,7^{\circ} \mathrm{C}$ with a relative air humidity of $\% 60$ until transfer to the hatcher on day 18 and relative air humidity was $80 \%$ in hatcher). After unfertilized or with dead embryos were discarded by illumination at $12 \mathrm{~d}$ of incubation, fertile 182 eggs weighed and divided into 2 equal weight eggs groups (control no injection (90 egg) and in ovo injection of $S C$ (92 eggs)). At $18 \mathrm{~d}$ of incubation, the blunt side of the egg was sterilized with $70 \%$ ethanol. Saccharomyces cerevisiae product provided from Global Nutritech company at powder form and it includes $4 \times 10^{9} \mathrm{cfu} / \mathrm{g}$ live SC. Saccharomyces cerevisiae product was diluted in 10 $\mathrm{g} / 90 \mathrm{ml}$ distilled water and 0,2 $\mathrm{ml}$ solution for per egg and vehicle solution generated with $0.5 \% \mathrm{NaCl}$. The hatchery was heated to $35{ }^{\circ} \mathrm{C}$ before application and injection carried out in 10 minute for per group. In ovo administration of $S C 0.2 \mathrm{ml}$ per egg was applied through air sac of the blunt side of the eggs by using a 21-gauge needle. $8 \times 10^{7} \mathrm{SC}$ provided for per eggs

After hatching, 160 day old healthy chicks were housed according to belonging treatment groups (Battery cages) with 10 replicates and 4 chicks per replicate for 14 days. Battery cages $(100 \mathrm{~cm} \times 50 \mathrm{~cm} \times 40 \mathrm{~cm})$ were equipped with wire mesh, dropping trays, nipple drinkers and trough feeders. The battery cages were placed in an environmentally controlled room with windows. Treatment groups were A) in ovo SC injection + dietary SC supplementation, B) in ovo $S C$ injection + basal diet, C) no injection + dietary SC supplementation, D) no injection + basal diet as control. Chicks were fed in mash form feed and watered ad-libitum with $23 \mathrm{~h}$ continuous illumination by fluorescence lamp per day. Experimental area temperature was $32^{\circ} \mathrm{C}$ at the beginning of the study and then gradually decreased to $30^{\circ} \mathrm{C}$ on $\mathrm{d} 14$ of the study. Birds were weighed weekly and feed consumption, feed conversion ratio and weight gain was calculated. Two birds ( 1 female and 1 male) randomly from each replication (20 chicks per treatment) were slaughtered at day 14 to determine proventriculus, gizzard, liver, gastro intestinal weight and length. Weights of edible inner organs (gizzard, heart and liver) were recorded as g/100 g body weight. Experimental diet includes 3.080 Mcal (metabolizable energy:ME) $\mathrm{kg}^{-1}$ and $22.39 \mathrm{~g}$ crude protein (CP) $\mathrm{kg}^{-1}$ (Table 1) and provided from commercial feed company at Kayseri in Turkey.

Ileum samples were taken and cut into $1.5 \mathrm{~cm}$ pieces and placed into $10 \%$ formalin for further processing. Tissues sections were placed into tissue cassettes for dehydration process and were embedded in paraffin blocks, and subsequently cut $10 \mu$ thickness and placed on a slide. Each ileal histomorhological tissue sample was prepared and stained with hematoxylin and eosin solution by using standard paraffin-embedding methods. After embedding process villi length and villi width were 
photographed and evaluated by using an image processing and analysis system (ZEN 2012 SP2).

Samples of the caecal contents were collected into sterile glass tubes in which they were kept on ice until subsequent inoculation into agars. MRS agar (MERCK, Darmstadt, Germany, 1.10660) was used for enumeration of lactic acid bacteria $(\mathrm{LAB})$ at $37^{\circ} \mathrm{C}$ for a $3 \mathrm{~d}$ incubation period and malt extract agar (MERCK, Darmstadt, Germany, 1.05398) was used for enumeration of yeast at $25^{\circ} \mathrm{C}$ for a $3 \mathrm{~d}$ incubation period. VRB (Violet Red Bile) (MERCK, Darmstadt, Germany, 1.01406) agar was used for enumeration of Enterobactericaea at $37^{\circ} \mathrm{C}$ for a $18-20$ $\mathrm{h}$ incubation period. Bacterial colonies were counted with determining the average number of live bacteria for per gram caecal contents. LAB, and Enterobactericaeacounts of the samples were converted into logarithmic colony forming units $\left(\mathrm{cfu} \mathrm{g}^{-1}\right)$. The data were analyzed using the general linear models procedure of SPSS software (SPSS 15). Differences between groups' means were separated by Duncan's multiple range.

\section{Results and Discussion}

The results of this study showed that both in ovo $S C$ injection and dietary $S C$ supplementation increased $14 \mathrm{~d}$ growth of broiler chicks. Performance parameters are given in Table 3. C group's $14 \mathrm{~d}$ growth was found to be the highest compared to other groups. This result may be indicator for in ovo SC injection must have increased the efficiency of dietary SC supplementation. Feed consumption and FCR were similar among the experimental groups. The result of this study was similar to earlier studies. Çelik et al. (2001), Santin et al. (2001), Jayanese et al. (2017), Koç et al. (2010), Gil de Los Santos et al. (2005) reported that dietary SC supplementation increased broiler growth performance. Also, it was reported that dietary $S C$ supplementation moderate negative effects of anti nutritional factors such as aflatoxin and ochratoxin in broilers by increasing growth (Kemal et al., 2003; Karaman et al., 2005); Yildiz et al., 2004; Mendieta et al., 2017). Internal organs were not affected by SC in ovo injection or supplementation among the groups except for gizzard. Gizzard was found higher in A group from D group.

The effects of in ovo $S C$ injection to fertile broiler eggs and dietary $S C$ supplementation on gut histomorhological parameters of broilers are given in Table 5. Duodenum histomorhological parameters did not differ among the experimental groups. Jejunal villi length increased in $\mathrm{A}, \mathrm{B}$, and $\mathrm{C}$ groups from than $\mathrm{D}$ group ( $P>0.05)$. Jejunal villi length of $A$ group was found to be higher compared to $\mathrm{B}$ and $\mathrm{C}$ groups $(\mathrm{P}>0.05)$. Villi length/villi width ratio was not different in jejunum. The in ovo feeding and dietary supplementation of SC was significantly affected villi length $(\mathrm{P}>0.01)$, interaction effect was also found to be significant. Jejunal villi width in $\mathrm{A}$ and $\mathrm{C}$ group was higher than $\mathrm{B}$ and $\mathrm{D}$ groups $(\mathrm{P}>0.05)$. Ileal villi length was higher in $\mathrm{A}$ and $\mathrm{C}$ groups from $B$ and $D$ groups $(\mathrm{P}>0.05)$.

The effect of dietary $S C$ supplementation on ileal villi length was very important $(\mathrm{P}>0.01)$. Villi width in ileum was not different among the groups. Villi length/villi width in ileum was higher in A group from D group (P>0.05). The effect of dietary $S C$ supplementation on villi length/villi width in ileum was important $(\mathrm{P}>0.05)$. This result on villi parameters in digestive tract may be indicator of which in ovo $S C$ injection and dietary $S C$ supplementation together or alone increased digestion surface area. It can be concluded that in ovo $S C$ injection may increase efficiency of dietary $S C$ supplementation. Because, the result of current study showed a better activity of gut gut histomorphology and digestion. Koç et al., (2010) and Sozcu and Ipek, (2017) showed that dietary $S C$ supplied with MOS as symbiotic is more effective than individual $S C$ supplementation.

Table 1 Composition and calculated analyses of the basal diets (DM, \%)

\begin{tabular}{|c|c|}
\hline Ingredients & $\mathrm{g} / \mathrm{kg}$ as fed \\
\hline Corn & 440.00 \\
\hline Soybean meal (\%44) & 411.50 \\
\hline Meatand bone meal & 40.00 \\
\hline Vegetableoil & 65.00 \\
\hline Di-calciumphosphate & 2.50 \\
\hline L-lysine, $\mathrm{HCl}$ & 0.70 \\
\hline DL-methionine & 0.35 \\
\hline Salt & 0.30 \\
\hline Vitamin premix* & 0.25 \\
\hline Mineral premix $* *$ & 0.25 \\
\hline Total & 1000.00 \\
\hline \multicolumn{2}{|c|}{ Analyzed nutrient composition } \\
\hline Metabolizable energy $(\mathrm{kcal} / \mathrm{kg})$ & 3080 \\
\hline Crude protein, $\%$ & 22.39 \\
\hline Crude fiber, $\%$ & 2.80 \\
\hline Etherextract, \% & 8.50 \\
\hline Calcium, $\%$ & 7.60 \\
\hline Availablephosphorus \% & 3.80 \\
\hline
\end{tabular}


Table 2 The effects of in ovo injection of Saccharomyces cerevisiae to fertile broiler eggs on hatchability of hatched chicks

\begin{tabular}{l|ccc}
\hline \multicolumn{1}{c|}{ In ovo injection } & + & - & $\mathrm{f}$ \\
\hline Hatchability, \% & $\% 90,25$ & $\% 90,00$ & 0,93 \\
(n) & $(92)$ & $(90)$ & \\
\hline
\end{tabular}

Table 3 The effects of in ovo Saccharomyces cerevisiae injection to fertile broiler eggs and dietary supplementation on performance parameters of broiler chicks.

\begin{tabular}{l|cccccccc}
\hline \multicolumn{1}{c|}{ In ovo injection } & \multicolumn{3}{c}{+} & \multicolumn{3}{c}{} & \multicolumn{3}{c}{ P Value } \\
\hline Dietary supplementation & + & - & + & - & SEM & IOF & DS & INT \\
Groups & A & B & C & D & & & \\
LWG $(\mathrm{g})$ & $322.76^{\mathrm{ab}}$ & $333.07^{\mathrm{ab}}$ & $345.20^{\mathrm{a}}$ & $306.45^{\mathrm{b}}$ & 5.35 & 0.82 & 0.14 & 0.02 \\
FI (g) & 472.20 & 489.39 & 514.03 & 474.88 & 14.46 & 0.67 & 0.73 & 0.39 \\
FCR & 1.46 & 1.47 & 1.49 & 1.55 & 0.03 & 0.53 & 0.69 & 0.76 \\
\hline
\end{tabular}

${ }^{\mathrm{a}, \mathrm{b}}$ Means in the same row not sharing a common superscript differ significantly $(\mathrm{P}<0.05), \mathrm{SEM}=\mathrm{Standard}$ error of the mean, LWG $=\mathrm{Live}$ weight gain, FI= Feed intake, FCR= Feed converson ratio, $\mathrm{IOF}=\mathrm{In}$ ovo feeding, DS=Dietary supplementation, INT= Interaction effect

Table 4 The effects of in ovo Saccharomyces cerevisiae injection to fertile broiler eggs and dietary supplementation on inner organ developments of broiler chicks, $1=\mathrm{g} / 100 \mathrm{~g} \mathrm{BW}, 2=\mathrm{cm} / 100 \mathrm{~g} \mathrm{BW}$

\begin{tabular}{l|cccccccc}
\hline \multicolumn{1}{c}{ In ovo injection } & \multicolumn{3}{c}{+} & \multicolumn{3}{c}{-} & \multicolumn{3}{c}{ P Value } \\
\hline Dietary supplementation & + & - & + & - & SEM & IOF & DS & INT \\
Groups & $\mathrm{A}$ & $\mathrm{B}$ & $\mathrm{C}$ & $\mathrm{D}$ & & & & \\
Heart $^{1}$ & 0.74 & 0.69 & 0.77 & 0.71 & 0.013 & 0.41 & 0.03 & 0.71 \\
Liver $^{1}$ & 3.56 & 3.45 & 3.48 & 3.50 & 0.051 & 0.86 & 0.71 & 0.58 \\
Gizzard $^{1}$ & $5.22^{\mathrm{a}}$ & $4.88^{\mathrm{ab}}$ & $4.86^{\mathrm{ab}}$ & $4.57^{\mathrm{b}}$ & 0.090 & 0.06 & 0.08 & 0.90 \\
GITL $^{2}$ & 34.07 & 35.01 & 33.83 & 34.13 & 0.586 & 0.66 & 0.62 & 0.80 \\
Pancreas $^{1}$ & 0.54 & 0.46 & 0.49 & 0.52 & 0.015 & 0.83 & 0.34 & 0.09 \\
Bursa fabricious $^{1}$ & 0.25 & 0.24 & 0.21 & 0.23 & 0.009 & 0.14 & 0.58 & 0.50 \\
Proventriculus $^{1}$ & 0.85 & 0.86 & 0.81 & 0.82 & 0.022 & 0.37 & 0.91 & 0.98 \\
\hline
\end{tabular}

${ }^{\mathrm{a}, \mathrm{b}}$ Means in the same row not sharing a common superscript differ significantly $(\mathrm{P}<0.05), \mathrm{SEM}=$ Standard error of the mean, IOF= In ovo feeding, DS=Dietary supplementation, INT= Interaction effect, BW= Body weight, GITL= Gastro intestinal length.

Table 5 The effects of in ovo Saccharomyces cerevisiae injection to fertile broiler eggs and dietary supplementation on gut histomorpholgical parameters of broiler chicks

\begin{tabular}{|c|c|c|c|c|c|c|c|c|}
\hline \multirow{2}{*}{$\frac{\text { In ovo injection }}{\text { Dietary supplementation }}$} & \multicolumn{2}{|c|}{+} & \multicolumn{2}{|c|}{-} & \multirow[b]{2}{*}{ SEM } & \multicolumn{3}{|c|}{ P Value } \\
\hline & + & - & + & - & & IOF & DS & INT \\
\hline Groups & A & $\mathrm{B}$ & $\mathrm{C}$ & $\mathrm{D}$ & & & & \\
\hline \multicolumn{9}{|l|}{$\operatorname{Duodenum}(\mu)$} \\
\hline V1 & 761.10 & 789.27 & 756.95 & 749.28 & 9.23 & 0.26 & 0.60 & 0.36 \\
\hline VW & 87.62 & 94.23 & 90.90 & 93.70 & 1.82 & 0.72 & 0.22 & 0.62 \\
\hline V1/VW & 9.05 & 8.70 & 8.61 & 8.33 & 0.21 & 0.36 & 0.48 & 0.94 \\
\hline \multicolumn{9}{|l|}{ Jejunum $(\mu)$} \\
\hline V1 & $487.32^{\mathrm{a}}$ & $424.21^{\mathrm{b}}$ & $430.22^{\mathrm{b}}$ & $372.16^{\mathrm{c}}$ & 7.53 & 0.001 & 0.001 & 0.80 \\
\hline VW & $115.66^{\mathrm{a}}$ & $90.84^{c}$ & $101.89^{\mathrm{b}}$ & $85.07^{c}$ & 2.41 & 0.011 & 0.001 & 0.29 \\
\hline V1/VW & 4.21 & 4.67 & 4.22 & 4.37 & 0.09 & 0.09 & 0.84 & 0.44 \\
\hline \multicolumn{9}{|l|}{$\operatorname{Ileum}(\mu)$} \\
\hline $\mathrm{Vl}$ & $421.25^{\mathrm{a}}$ & $351.53^{b}$ & $391.59^{\mathrm{a}}$ & $344.93^{b}$ & 6.60 & 0.10 & 0.001 & 0.29 \\
\hline VW & 93.42 & 89.63 & 92.09 & 91.03 & 2.21 & 0.90 & 0.51 & 0.87 \\
\hline V1/VW & $4.51^{\mathrm{a}}$ & $3.95^{\mathrm{ab}}$ & $4.25^{\mathrm{ab}}$ & $3.79^{\mathrm{b}}$ & 0.12 & 0.38 & 0.02 & 0.89 \\
\hline
\end{tabular}

$\bar{a}_{\mathrm{a}, \mathrm{b}}$ Means in the same row not sharing a common superscript differ significantly $(\mathrm{P}<0.05), \mathrm{SEM}=$ Standard error of the mean, IOF= In ovo feeding, DS=Dietary supplementation, INT= Interaction effect, Vl= Villi length, VW= Villi width.

Table 6 The effects of in ovo Saccharomyces cerevisiae injection to fertile broiler eggs and dietary supplementation on gut microflora of broiler chicks

\begin{tabular}{l|cccccccc}
\multicolumn{1}{c}{ In ovo injection } & \multicolumn{3}{c}{+} & \multicolumn{3}{c}{-} & & \multicolumn{2}{c}{ P Value } \\
\hline Dietary supplementation & + & - & + & - & SEM & IOF & DS & INT \\
Groups & $\mathrm{A}$ & $\mathrm{B}$ & $\mathrm{C}$ & $\mathrm{D}$ & & & \\
Enterobactericaea & $3.64^{\mathrm{a}}$ & $3.72^{\mathrm{a}}$ & $3.87^{\mathrm{ab}}$ & $4.08^{\mathrm{b}}$ & 0.06 & 0.006 & 0.060 & 0.267 \\
LAB & $2.37^{\mathrm{b}}$ & $2.28^{\mathrm{ab}}$ & $1.94^{\mathrm{a}}$ & $1.86^{\mathrm{a}}$ & 0.03 & 0.001 & 0.003 & 0.993 \\
\hline
\end{tabular}

${ }^{\mathrm{a}, \mathrm{b}}$ Means in the same row not sharing a common superscript differ significantly $(\mathrm{P}<0.05), \mathrm{SEM}=$ Standard error of the mean, IOF= In ovo feeding, $\mathrm{DS}=$ Dietary supplementation, INT $=$ Interaction effect, $\mathrm{LAB}=$ lactic acid bacteria. 
Caecal lactic acid bacteria count was higher in A group from $\mathrm{C}$ and $\mathrm{D}$ group $(\mathrm{P}<0.05)$. Caecal Enterobactericaea count was higher in A and B group than in the control group $(\mathrm{P}<0.05)$. The effect of in ovo $S C$ injection and dietary $S C$ supplementation on caecal lactic acid bacteria and Enterobactericaea count was significant $(\mathrm{P}<0.05)$, interaction effect was not important (Table 6). The result of this study showed that both in ovo $S C$ injection and dietary $S C$ supplementation suppressed pathogenic bacteria and increased LAB count in cecum. In earlier studies, it has been showed that dietary probiotic supplementation to poultry diet suppress the pathogenic bacteria in bird's digestive tract and it facilitates a barrier between the intestinal wall and the lumen of gut for the pathogenic bacteria. Probiotics in a chick's digestive tracts enhances the volatile fatty acids (VFA) production. Increased VFA levels alleviate the $\mathrm{pH}$ in chicks gut. Lowering the $\mathrm{pH}$ and increased VFA create an unfavorable environment for pathogens (Samli et al., 2007). Although VFA was not investigated in the present study, decreased the caecal Enterobactericaea and increased LAB count with dietary SC supplementation may be an indicator of increased VFA in cecum.

To conclude, in ovo SC injection increased the efficiency of dietary SC supplementation by increasing gut histomorphology, digestion surface area in ileum, LAB count in ceacum and decreasing Enterobactericaea in broiler chicks. However, further studies should be conducted to determine the effects of in ovo injection of different probiotics, prebiotics or symbiotic for broiler chicks gut health to increase performance.

\section{Acknowledgements}

This research was a MSc thesis of the first author. This research study was supported by The Scientific Research Project Office of Ahi Evran University (PYOZRT-4001.16.004).

\section{References}

Chen F, Zhu L, Qiu H, Qin S. 2017a. Selenium enriched Saccharomyces cerevisiae improves growth, antioxidant status and selenoprotein gene expression in Arbor Acres broilers. Journal of Animal Physiology and Animal Nutrition. 101: 259-266.

Chen CY, Chen SW, Wang HT. 2017b. Effect of supplementation of yeast with bacteriocin and Lactobacillus culture on growth performance, caecal fermentation, microbiota composition, and blood characteristics in broiler chickens. Asian-Australasian journal of animal sciences, 30(2): 211

Coskun I, Erener G, Cayiroglu H, Altop A, Cayan H, Sahin A. 2017. Effects of dietary symbiotic csupplementation on growth performance and duodenum histology of Japanese quail (Coturnix coturnix Japonica) reared in different flooring systems. Revista Brasileira de Zootecnia, 46(10): 800-804.

Celik K, Denli M, Ozturkcan O. 2001. The effects of Saccharomyces cerevisiae and flavomycin on broiler growth performance. Pakistan Journal of Biological Sciences, 4(11): 1415-1417.
De Souza LF, Araújo DN, Stefani LM, Giometti IC, CruzPolycarpo VC, Do Valle Polycarpo G, Burbarelli MF. 2018. Probiotics on performance, intestinal morphology and carcass characteristics of broiler chickens raised with lower or higher environmental challenge. Austral Journal of Veterinary Sciences, 50(1): 35-41.

Gil de los santos JR, Storch OB, Gil-turnes C. 2005. Bacillus cereus var. toyoii and Saccharomyces boulardii increased feed efficiency in broilers infected with Salmonella enteritidis, British Poultry Science, 46: 4,494-497, DOI: 10.1080/00071660500181461

Gunal M, Yayli G, Kaya O, Karahan N, Sulak O. 2006. The effects of antibiotic growth promoter, probiotic or organic acid supplementation on performance, intestinal microflora and tissue of broilers. International Journal of Poultry Science, 5(2): 149-155.

Haldar S, Ghosh TK, Bedford MR. 2011. Effects of yeast (Saccharomyces cerevisiae) and yeast protein concentrate on production performance of broiler chickens exposed to heat stress and challenged with Salmonella enteritidis. Animal feed science and technology, 168(1): 61-71.

Jayasena DD, Tharangani RH, Song Z, Heo JM. 2017. Determination of The Growth Performances and Meat Quality of Broilers Fed Saccharomyces cerevisiae as a Probiotic in Two Different Feeding Intervals. Korean Journal of Poultry Science. 44(3): 161-172.

Karaman M, Basmacioglu H, Ortatatli M, Oguz H. 2005. Evaluation of the detoxifying effect of yeast glucomannan on aflatoxicosis in broilers as assessed by gross examination and histopathology. British poultry science, 46(3): 394-400

Karaoglu M, Durdag H. 2005. The influence of dietary probiotic (Saccharomyces cerevisiae) supplementation and different slaughter age on the performance, slaughter and carcass properties of broilers. International Journal of Poultry Science, 4(5): 309-316.

Kemal Ç, Muzaffer D, Türker S. 2003. Reduction of toxic effects of aflatoxin B1 by using baker yeast (Saccharomyces cerevisiae) in growing broiler chicks diets. Revista Brasileira de Zootecnia, 32(3): 615-619.

Koç F, Samli H, Okur A, Ozduven M, Akyurek H, Senkoylu N. 2010. Effects of Saccharomyces cerevisiae and/or mannanoligosaccharide on performance, blood parameters and intestinal microbiota of broiler chicks. Bulgarian Journal of Agricultural Science, 16(5): 643-650.

Mendieta CR, Gómez GV, Del Río JCG, Cuevas AC, Arce JM, Ávila EG. 2017. Effect of the Addition of Saccharomyces cerevisiae Yeast Cell Walls to Diets with Mycotoxins on the Performance and Immune Responses of Broilers. The Journal of Poultry Science, 0170019.

Ozturk E, Yildirim A, 2004. Probiyotiklerin etlik piliçlerin performansı ve bağırsak mikrobiyolojik özelliklerine etkileri. Ulusal Zootekni Bilim Kongresi, Cilt 2. 152-156, ISPARTA.

Samli HE, Senkoylu N, Koc F, Kanter M, Agma A. 2007. Effects of Enterococcus faecium and Dried whey on broiler performance, gut histomorphology and intestinal microbiota. Archives of Animal Nutrition 61: 42-49.

Santin E, Maiorka A, Macari M, Grecco M, Sanchez J C, Okada TM, Myasaka AM. 2001. Performance and intestinal mucosa development of broiler chickens fed diets containing Saccharomyces cerevisiae cell wall. Journal of Applied Poultry Research, 10(3): 236-244.

Sozcu A, Ipek A. 2017. Intestinal morphology, hepatic enzyme activity, serum immunoglobulin level and growth performance of broilers fed on diets supplemented with a synbiotic. European Poultry Science, 81. 
Teng PY, Chung CH, Chao YP, Chiang CJ, Chang SC, Yu B, Lee TT. 2017. Administration of Bacillus Amyloliquefaciens and Saccharomyces cerevisiae as direct-fed microbials improves intestinal microflora and morphology in broiler chickens. The Journal of Poultry Science, 54(2): 134-141.

Yasar S, Yegen MK. 2017. Yeast fermented additive enhances broiler growth. Revista Brasileira de Zootecnia. 46, 814820.
Yildiz AO, Parlat SS, Yildirim I. 2004. Effect of dietary addition of live yeast (Saccharomyces cerevisiae) on some performance parameters of adult Japanese quail (Coturnix coturnix japonica) induced by aflatoxicosis. Revue de médecine vétérinaire, 155(1): 38-41. 